\title{
Effect of Polyethylene Glycol on the Synthesis of Oligopeptide by Papain in an Organic Medium
}

\author{
Yoshiaki Hirano, Tadamasa Terai, Kunio Goto \\ and Akio NAKAJIMA \\ Department of Applied Chemistry, Osaka Institute of Technology, \\ Ohmiya 5-16-1, Asahi-ku, Osaka 535, Japan \\ Received January 24, 1991
}

\begin{abstract}
The enzymic peptide synthesis in an organic medium was investigated by using papain in the presence of PEG. The added PEG enhanced the enzyme activity of papain for synthesis of the peptide, Boc-Gly-Asp(OBzl)OBzl. The activity of papain in the PEG-added system was higher than that in a PEG-free system.
\end{abstract}

In rature, enzymes function mainly in an aqueous solution. However, in the last few years, many investigations have been carried out $^{1-7)}$ on enzymic reactions in an organic solvent. For example, the use of proteolytic enzymes (e.g., proteases) to catalyze peptide bond formation may become one of the promising synthetic methods of the future. ${ }^{5-10}$ ) The principle involved depends on shifting the chemical equilibrium toward the peptide bond formation. The enzymic synthesis of peptides proceeds at room temperature in a buffered aqueous-organic solution and, under such mild conditions, it should minimize or eliminate the possibility of side reactions which might occur in conventional chemical coupling.

Recently, many studies have been reported on the chemical modification of enzymes by a covalent bond with synthetic macromolecules soluble in both water and organic solvents. The modified enzymes were soluble in organic solvents such as benzene, toluene and chlorinated hydrocarbons, and exhibited high enzymic activity in these organic solvents. ${ }^{8-14)}$ On the other hand, the modification of an enzyme may block the active site of the enzyme, destroy its conformation, and so on. ${ }^{15)}$ In this paper, we describe the effect of polyethylene glycol (PEG) on enzymic peptide synthesis in an organic solvent, without forming covalent bonds between PEG and the enzyme. An amino-protected amino acid was coupled with a carboxyl-protected amino acid to give a dipeptide, tert-butyloxycarbonyl-glycyl-Lasparatic $\alpha, \beta$-dibenzyl ester (Boc-Gly-Asp(OBzl)OBzl), by papain (EC 3.4.22.2) in an organic solvent containing a small amount of water and PEG. The reaction products, Boc-Gly, Asp(OBzl)OBzl and Boc-Gly-Asp$(\mathrm{OBzl}) \mathrm{OBzl}$, were examined by of gel permeation chromatography (GPC), and the rate of reaction was calculated from the GPC data.

\section{Materials and Methods}

Materials. All the enzymes, chemicals and solvents used were of reagent grade. tert-Butyloxycarbonyl-glycine (Boc-Gly) and L-aspartic acid $\alpha, \beta$-dibenzyl ester (Asp(OBzl)OBzl) were purchased from Peptide Institute (Osaka, Japan). Papain (EC 3.4.22.2; from carica papaya, water-soluble $30,000 \mathrm{USP} / \mathrm{mg}$ ) was from Merck Inc. Polyethylene glycol (PEG), whose molecular weight was about 4,000, was obtained from Kawaken Fine Chemicals (Osaka, Japan). GPC measurements were carried out with a TOSOH GPC system consisting of a CCPD pump unit, RI-8012 RI detector, and TOSOH column (TSK-GEL H type), using a mobile phase of THF at a flow-rate: $800 \mu \mathrm{l} \cdot \min ^{-1}$.

Preparation of the calibration curves. Calibration curves for the peptides, Boc-Gly, Asp(OBzl)OBzl, and a Boc-Gly and $A s p(O B z l) O B z l$ mixture, and Boc-Gly-Asp(OBzl)OBzl (Fig. 1), were obtained from the relationship between the peptide concentration $(0.3,0.6,0.9$ and $1.2 \mathrm{mmol} / \mathrm{l}$ of THF solution) and the peak area in GPC chromatograms. 
Selection of the reaction solvent. The organic solvents, methanol, dioxane, dimethylformamide (DMF), dimethylsulfoxide (DMSO), tetrahydrofuran (THF), ethylacetate, chloroform, 1,1,1-trichloroethane (TCE), ${ }^{16)}$ benzene and toluene, were tested in this reaction system. $0.2 \mathrm{mmol}$ Boc-Gly (35.0 mg) and $0.2 \mathrm{mmol} \mathrm{Asp(OBzl)OBzl}(62.7 \mathrm{mg})$ were dissolved in $5 \mathrm{ml}$ of a solvent, to which $40 \mathrm{mg}$ of $P E G$, $5 \mathrm{mg}$ of papain and $0.1 \mathrm{ml}$ of a phosphate buffer solution (pH 6.4, PBS) had been added. The mixture was stirred for $24 \mathrm{hr}$ at $25^{\circ} \mathrm{C}$ to check the percentage of the reaction.

Synthesis of dipeptides by papain in organic solvents in the presence of PEG. $0.2 \mathrm{mmol}$ Boc-Gly (35.0 mg) and $0.2 \mathrm{mmol} \mathrm{Asp}(\mathrm{OBzl}) \mathrm{OBzl}(62.7 \mathrm{mg})$ were dissolved in $5 \mathrm{ml}$ of TCE, to which $5 \mathrm{mg}$ of papain, PEG $(0-50 \mathrm{mg})$ and PBS $(0.1-0.5 \mathrm{ml})$ had been added. $0.04 \mathrm{M}$ Ethylenediaminetetraacetic acid (EDTA) was added to PBS to remove the metal ion as an inhibitor, and $0.01 \mathrm{M}$ L-cysteine (L-Cys) was added to activate the agent for papain. The optimum reaction conditions obtained were as follows: $0.2 \mathrm{mmol}$ substrate, $0.1 \mathrm{ml}$ of PBS and $40 \mathrm{mg}$ of PEG in $5 \mathrm{ml}$ of TCE. Experiments were also carried out to obtain information on the effect of adding EDTA and L-Cys to PBS or to pure water for peptide synthesis. All the mixtures were stirred for $24 \mathrm{hr}$ at $25^{\circ} \mathrm{C}$, the reaction system being a suspension of TCE and PBS with stirring, and PEG was soluble in both TCE and PBS. The solubility of TCE in water was $0.44 \mathrm{~g}$ per $100 \mathrm{~g}$ of $\mathrm{H}_{2} \mathrm{O}$, and that of $\mathrm{H}_{2} \mathrm{O}$ in TCE was $0.05 \mathrm{~g}$ per $100 \mathrm{~g}$ of TCE, both at $20^{\circ} \mathrm{C}$. After evaporating TCE from the reaction mixture, $5 \mathrm{ml}$ of THF was added to dissolve the resultant dipeptide, and the insoluble residue was removed by filtration. The product was identified by GPC.

The effect of the reaction temperature, reaction time and concentration of the substrate on dipeptide synthesis was investigaged to find the best conditions. The optimum reaction conditions obtained were as follows: $0.2 \mathrm{mmol}$ substrate, $0.1 \mathrm{ml}$ of PBS containing EDTA and L-Cys, and $40 \mathrm{mg}$ of $\mathrm{PEG}$ in $5 \mathrm{ml}$ of $\mathrm{TCE}$. The reaction temprature and reaction time were checked under these conditions. The initial rates $[v]$ were calculated for different substrate concentrations $([S]=2500-200 \mathrm{mmol} / \mathrm{l})$, and the MichaelisMenten constant $\left(K_{m}\right)$ was estimated.

\section{Results and Discussion}

\section{Preparation of the calibration curves}

Figure 1 shows the calibration curves for Boc-Gly, Asp(OBzl)OBzl, and Boc-Gly-Asp(OBzl)OBzl obtained from gel permeation chromatography. The peak areas were directly proportional to the concentrations of amino acid and dipeptide in THF. The calibration curves were used to estimate the percentage of the reaction, and the concentration of the

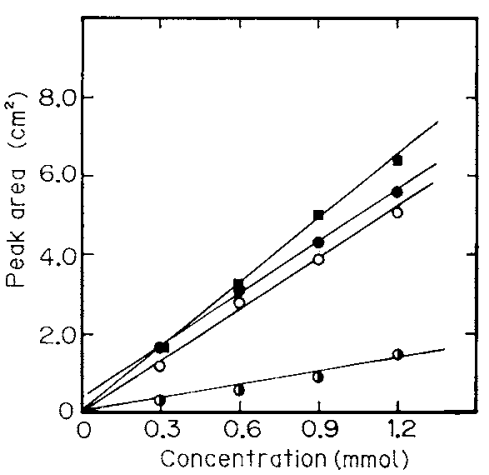

Fig. 1. Calibration Curves for the Amino Acids and Dipeptides Obtained by GPC.

D, Boc-Gly; O, Asp(OBzl)OBzl; - Boc-Gly and Asp(OBzl)OBzl; $\boldsymbol{\square}$, Boc-Gly-Asp(OBzl)OBzl.

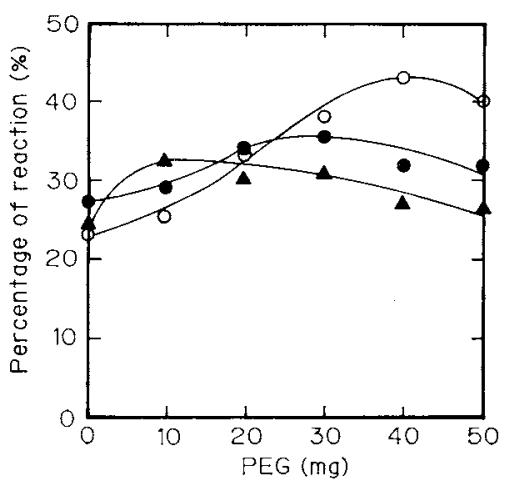

Fig. 2. Relationship between the Percentage of Reaction and Amount of PEG.

Phosphate buffer: $0,0.1 \mathrm{ml} ; 0.3 \mathrm{ml} ; \mathbf{\Delta}, 0.5 \mathrm{ml}$.

substrate.

\section{Selection of a solvent for the reaction}

TCE was the best solvent for this reaction among the solvents tested. The percentage of reaction in the solvents tested were methanol, $0 \%$; dioxane, $0 \%$; DMF, $0 \%$; DMSO, $0 \%$; THF, $0 \%$; ethylacetate, $7 \%$; chloroform, $15 \%$; TCE, $45 \%$; benzene, $10 \%$; and toluene, $10 \%$. These data show that water-miscible solvents were not applicable to the reaction system.

Enzymic synthesis of dipeptide with papain in an organic medium containing $P E G$

The percentage of reaction was defermined from the GPC tests, Fig. 2 showing the relationship between the percentage of reaction 
Table I. Effect of Reaction Media and the Presence of EDTA and L-Cys on the Percentage of REACTION For PePtide Synthesis

\begin{tabular}{lllllll}
\hline Reaction medium & & \multicolumn{2}{c}{ PBS } & & \multicolumn{2}{c}{ Pure water } \\
\cline { 1 - 3 } \cline { 5 - 6 } \cline { 5 - 6 } Amount of PEG & & $40 \mathrm{mg}$ & $0 \mathrm{mg}$ & & $40 \mathrm{mg}$ & $0 \mathrm{mg}$ \\
\hline $\begin{array}{l}\text { Precentage of reaction } \\
\text { in the presence of }\end{array}$ & $45 \%$ & $24 \%$ & & $40 \%$ & $19 \%$ \\
$\begin{array}{l}\text { EDTA and L-Cys } \\
\begin{array}{l}\text { Percentage of reaction } \\
\text { in the absence of EDTA } \\
\text { and L-Cys }\end{array}\end{array}$ & $34 \%$ & $22 \%$ & $34 \%$ & $14 \%$ \\
\hline
\end{tabular}

and the amount of PEG added in a PBS buffer solution (A, $0.1 \mathrm{ml} ; \mathrm{B}, 0.3 \mathrm{ml}$; and $\mathrm{C}, 0.5 \mathrm{ml}$ ). For all the systems containing PEG, the percentage of reaction was higher than that of a PEG-free system. As obvious from Fig. 2, the amounts of PBS and PEG were important to produce dipeptide in a high yield. It is presumed that, in the PEG-added system, the enzyme and water were homogeneously dispersed the in organic medium, and that PEG functioned as a surface-active agent. The maximum percentage of reaction was found with $40 \mathrm{mg}$ of PEG, $0.1 \mathrm{ml}$ of PBS containing EDTA, and L-Cys in $5 \mathrm{ml}$ TCE. Boc-GlyAsp(OBzl)OBzl was obtained as an oily product in a $25-30 \%$ yield. Table I shows the effect on peptide synthesis of adding EDTA and L-Cys to PBS or to pure water. These data suggest that this reaction system needs EDTA and L-Cys in PBS. This result may suggest that, in an aqueous medium, papain catalyzed the hydrolytic reaction; however, in an organic solvent containing a small amount of water and PEG, it catalyzed the dipeptide bond formation, the reverse of the hydrolysis reaction, changing from a hydrolytic reaction with high water concentration to peptide bond formation with very low water concentration.

\section{Relationship between the percentage of reaction and reaction temperature}

Figure 3 shows the relationship between the percentage of reaction and the reaction temperature. In both the PEG-added system and

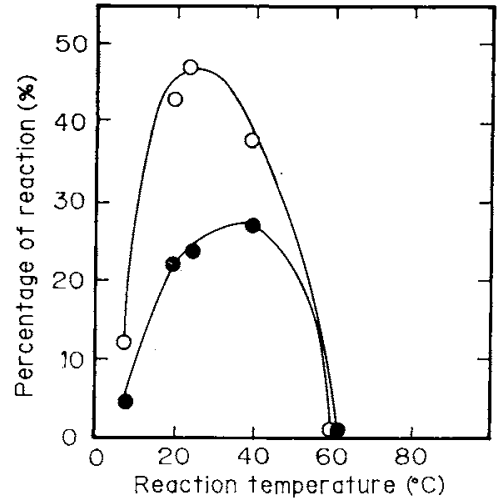

Fig. 3. Relationship between the Percentage of Reaction and Reaction Temperature for the PEG-added System (O) and PEG-free System

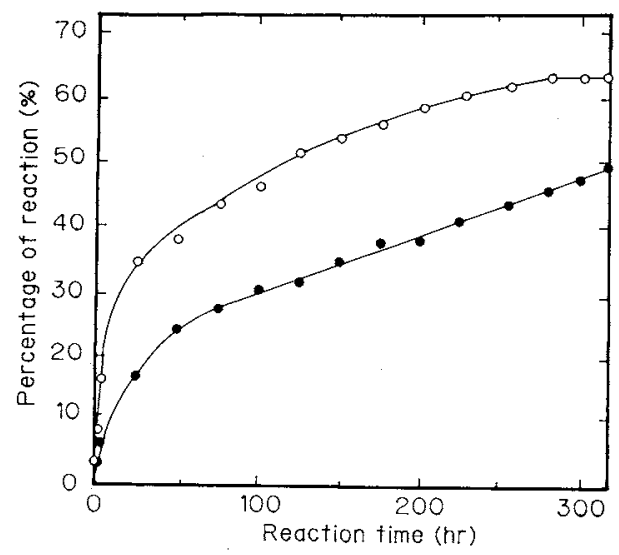

Fig. 4. Relationship between the Percentage of Reaction and Reaction Time for the PEG-added System $(O)$ and PEG-free System

PEG-free system, the maximum activity of the enzyme was obtained at $37^{\circ} \mathrm{C}$. At temperatures as high as $60^{\circ} \mathrm{C}$, the activity of the enzyme decreased to zero. In the higher temperature range, the activity of the enzyme in the PEG-added system was higher than that in the PEG-free system.

\section{Relationship between the percentage of reaction and reaction time}

Figure 4 is the time course of the reaction at $22^{\circ} \mathrm{C}$. Throughout the reaction period, the activity of the enzyme in the PEG-added system was higher than that in the PEG-free system. After $125 \mathrm{hr}$, the reaction rate of the PEG- 


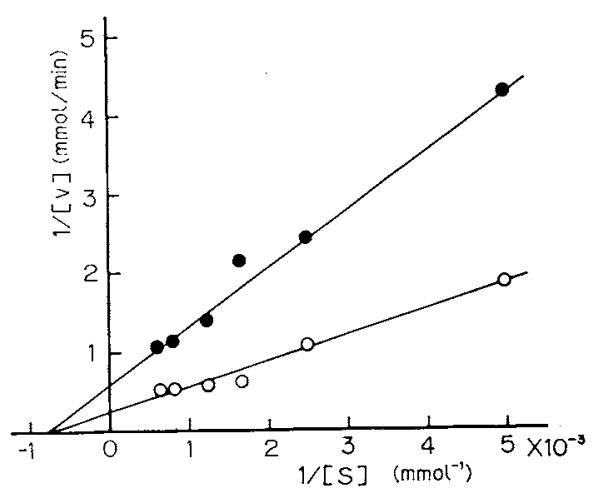

Fig. 5. Lineweaver-Burk Plots for the PEG-added System (O) and PEG-free System (O

added system decreased somewhat and finally seems to have leveled off at about $300 \mathrm{hr}$. In the PEG-free system, the percentage of reaction increased linearly after $100 \mathrm{hr}$. If the enzyme was not denatured in the PEG-free system, the reaction rate would have leveled off ultimately. $K_{m}$ values obtained for both reaction systems were the same (Table II), although the addition of PEG contributed to the reaction rate as an accelerator in this reaction system. We conclude from the $K_{m}$ values that PEG acted as an anti-non-competitive inhibitor for the enzyme in the PEG-added system.

\section{Reaction rate and Michaelis-Menten constant}

The initial reaction rate $[v]$ was obtained from the curve in a range from $0 \mathrm{~min}$ to $15 \mathrm{~min}$ at $22^{\circ} \mathrm{C}$. In Fig. 5, the reciprocal of the reaction rate $(1 /[v])$ is plotted against the reciprocal of the substrate concentration $(1 /[S])$, according to the Lineweaver-Burk equation. MichaelisMenten constant $K_{m}$ and maximum rate $V_{\max }$ obtained are shown in Table II, it being obvious from Table II that the addition of PEG enhanced the rate of peptide synthesis.

The reaction rate in the PEG-added system was about twice as fast as that in the PEG-free system, although the mechanism for the effect of PEG in this reaction is not clear. PEG, having both hydrophilic and hydrophobic characteristics, may have been adsorbed to the enzyme surface in the presence of a small amount of water, due to its hydrophilic nature,
Table II. $K_{m}$ And $V_{\max }$ Values Determined From Lineweaver-Burk Plots

\begin{tabular}{ccc} 
& $K_{m}(\mathrm{mmol})$ & $V_{\max }(\mathrm{mmol} / \mathrm{min})$ \\
$\begin{array}{c}\text { PEG-added system } \\
(\mathrm{PEG}=40 \mathrm{mg})\end{array}$ & $1.2 \times 10^{3}$ & 3.95 \\
PEG-free system & $1.3 \times 10^{3}$ & 1.68 \\
\hline
\end{tabular}

and the enzyme partly covered with PEG would introduce the substrates to the active site of the enzyme by this hydrophobic nature. Furthermore, this action did not damage the enzyme in an organic medium. Thus, the reaction rate was enhanced in the presence of PEG. From these facts, it was possible to synthesize dipeptide with a non-modified enzyme in an organic medium only adding PEG. This peptide synthesis described may be useful for obtaining a large quantity of peptides.

Acknowledgments. The authors thank Ms. Maki Kyuma and Ms. Miho Yoshida for their assistance in the experiments. This work was partly supported by a Grant-in-Aid to A.N. for Scientific Research (\#62604018) from the Ministry of Education, Science and Culture of Japan.

\section{References}

1) A. M. Klibarov, Chemtech, p. 354, June (1986).

2) T. Yamane, Yakugaku, 33, 683 (1984) (in Japanese).

3) N-J Tseng, S-H Wu and K-T Wang, Tetrahedron, 39, 61 (1983).

4) A. Zaks and A. M. Klibanov, J. Am. Chem. Soc,, 108, 2767 (1986).

5) A. Zaks and A. M. Klibanov, Proc. Natl. Acad. Sci. U.S.A., 82, 3192 (1985):

6) K. Nakanishi, Y. Kimura and R. Matsumoto, BIO/TECHNOLOGY, 4, 452 (1986).

7) J. S. Dordick, Enzyme Microb. Technol., 11, 194 (1989).

8) K. Takahashi, H. Nishimura, T. Yoshimoto, Y. Sato and Y. Inada, Biochem. Biophys. Res. Commun., 121, 261 (1984).

9) K. Takahashi, A. Ajima, T. Yoshimoto and Y. Inada, Biochem. Biophys. Res. Commun., 125, 761 (1984).

10) A. Matsushima, M. Okada and Y. Inada, FEBS Lett., 178, 275 (1984).

11) K. Nakanishi, T. Kamikubo and R. Matsumoto, BIO/TECHNOLOGY, 3, 459 (1985).

12) K. Yoshinaga, S. G. Shefer and J. M. Harris, $J$. Bioactive Compatible Polym., 2, 49 (1987). 
13) L. G. Butler, Enzyme Microb. Technol, 1, 253 (1979).

14) $Y$. Inada, T. Yoshimoto, A. Matsushima and $Y$. Saito, Tibtech, 1986, p. 68, March (1986).

15) Y. Inada, "Protein Hybrides," Kyoritsu-Shuppan,
Tokyo, 1987, pp. 1-23 (in Japanese).

16) Y. Inada, K. Takahashi, T. Yoshimoto, A. Ajima, A. Matsushima and Y. Saito, Tibtech, 1986, p. 190 , July (1986). 